\title{
Application of a coupled human natural system framework to organize and frame challenges and opportunities for biodiversity conservation on private lands.
}

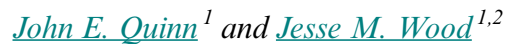

\begin{abstract}
Conservation science addresses the complementary goals of preventing future biodiversity loss while sustaining critical human foundations. In this paper we use two case studies focused on land management to discuss how private lands conservation can be more effective by considering how planning and decision making reflects a coupled human and natural system (CHANS). The first case study focuses on conservation easements in the temperate forests of eastern United States; the second focuses on conservation opportunities in Midwestern agroecosystems, in particular the value of agroforestry. For each case study we discuss the natural and human subsystems, how elements and interactions within and between subsystems (as organized by elements of CHANS) create challenges and opportunities for conservation, and the importance of considering relevant scales of subsystems. Review of these case studies demonstrates that additional insight gained by using a CHANS perspective, particularly given how the subsystems interact at different scales, improves identification of important points of social and ecological overlap, ultimately enhancing conservation research, planning, and practice.
\end{abstract}

Key Words: agriculture; avian; Blue Ridge; conservation easements; Midwest; Piedmont; scale

\section{INTRODUCTION}

Conservation biology is increasingly intersecting with sustainability science, where traditional nature conservation goals (Soulé 1985) are linked with priorities of food production (Quinn et al. 2014), poverty reduction (Brashares et al. 2014), and quality of life (Agarwala et al. 2014). Thus, conservation science researchers and practitioners are considering how conservation actions influence, and are influenced by, human systems (Kareiva and Marvier 2012). Understanding these connections is key to preventing future biodiversity loss while maintaining human social foundations (Raworth 2012). In this context, conserving biodiversity clearly becomes part of a coupled human and natural system (Liu et al. 2007). Given the benefits of systems thinking (Fiksel 2006), conservation research, decision making, planning, and practice would benefit from formally incorporating elements of coupled human and natural systems (CHANS) including heterogeneity, feedbacks, time lags and legacy effects, nonlinear dynamics with thresholds, and surprises. Furthermore, mounting evidence of cross-scale feedbacks and drivers between systems requires that conservation not be focused just on a single scale or system but also interactions within and between them.

Connections between human and natural systems are often implicitly discussed in regards to conceptualizations of conservation in human-modified ecosystems (reviewed in Martin et al. 2014). Explicit discussions of conservation biology as a CHANS are more limited. CHANS has been applied to evaluate how varied definitions of biodiversity affect practice and consideration of alternatives (Callicott et al. 2007), vulnerability of geophysical conditions in urban landscapes (Fan et al. 2014), and, uniquely, conservation of language and biodiversity on islands (Tershy et al. 2015). More closely aligned with a discussion of private lands, Strohbach et al. (2014) present urban wildlife conservation as an example of CHANS. Likewise, in a recent special issue on CHANS in this journal, Carter et al. (2014) discuss a CHANS approach to wildlife conservation, highlighting its value for linking different disciplines and leading to identification of new relationships and feedbacks that may not have been identified in previous analyses. Additionally, they discuss the value of considering relationships between people and biodiversity (or wildlife) across scales.

Applications of CHANS to biodiversity conservation, particularly the recent comparable case studies (e.g., Carter et al. 2014), focus largely on publicly protected land designated for conservation by government authorities, e.g., national parks or scientific reserves. Although a critical element of conservation efforts, these publicly protected lands are limited to $14.8 \%$ of global terrestrial area and $13.8 \%$ in the United States (World Bank 2015). Private lands, not managed by government authorities, cover $60 \%$ of the United States (USDA 2002). Given the extent of habitat loss and land use change and the lack of formal protection, private land represents an important conservation arena (Wallace et al. 2008). Private land conservation presents a different set of challenges to meeting conservation goals. Private lands are individually managed for multiple purposes including recreation, natural resource extraction, conservation, agriculture, aesthetics, and habitation. Decisions are often made on smaller units of land and reflect a different set or ordering of conservation priorities (Quinn et al. 2015, Dayer et al. 2016). That each parcel is embedded within different biome and anthrome types presents unique couplings within and between human and natural subsystems. To address this complexity, we illustrate the value of framing private land conservation as a coupling of human and natural systems across spatial and temporal scales, using case studies about local and landscape decisions from two crisis ecoregions (Hoekstra et al. 2005).

These case studies highlight dynamics within natural and human systems and how associated subsystems interact. The first case study focuses on the systems, elements, and interactions associated with conservation easements and temperate forest 
biomes threatened by urbanization. In the second case study we address the conservation value of agroforestry systems as a tool to align biodiversity conservation with biomass production. For both, we demonstrate how concurrent analyses of multiple systems provide opportunities to improve on past conservation efforts and reduce suboptimal decision making associated with conservation on private lands.

\section{NATURAL SUBSYSTEMS}

We first review natural subsystems (Fig. 1) in conservation efforts for temperate forest and agricultural biomes and anthromes (Fig. 2). The scale of each subsystem is presented to frame discussions about land management within the context of the case study. Though we focus initially on natural systems, it is clear that human systems shape the primary scale of interest (i.e., easements and farms), emphasizing the coupled nature of these systems. We frame our review with global trends and local habitat requirements of key species, choosing bird species as a lens with which to highlight implemented management practices and conservation strategies. Consideration of global change and local habitat frames the natural subsystems involved and provides a useful context for discussing specific conservation practices under a CHANS framework.

Fig. 1. Conceptual model of key human (blue) and natural (green) systems and subsystems and the interactions within and between systems.

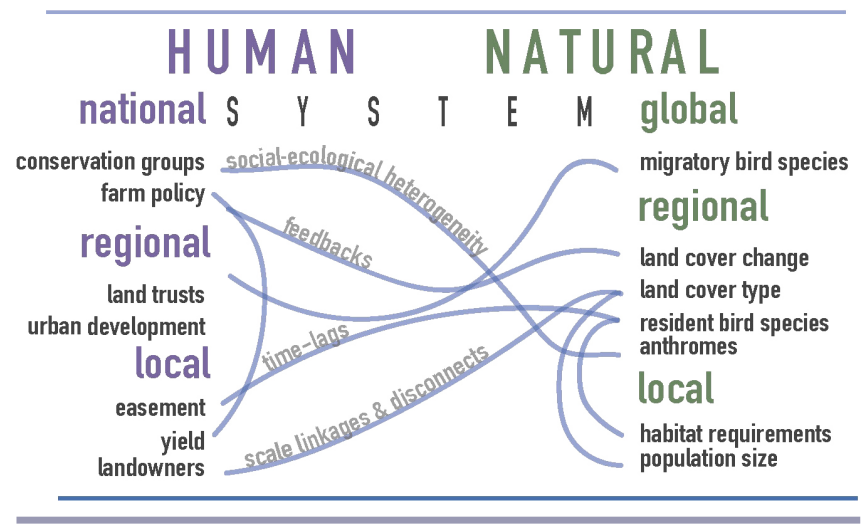

Case study \#1: Conservation easements in the western Carolinas The first case study focuses on private land conservation in temperate forests (Fig. 2), in particular forests threatened by rapid urbanization. Over $45 \%$ of global temperate forest cover has been lost (Hoekstra et al. 2005) while less than $10 \%$ of this biome is protected (Hoekstra et al. 2005). Historically dominated by mixed temperate hardwoods, the western halves of North and South Carolina (Fig. 2) have recently experienced a net loss of temperate forest cover, driven by socioeconomic shifts and population growth since the 1940s (Drummond and Loveland 2010). Much of the region's forests are fragmented, with isolated second and third successional growth forest patches scattered between developed urban and peri-urban areas. Consequently, the region might be better described as a populated or residential woodland anthrome (Ellis and Ramankutty 2008). Like patterns of protection in forest biomes, woodland anthromes comprise $11 \%$ of terrestrial surface but hold only $2 \%$ of protected lands (Martin et al. 2014).
Fig. 2. Regions represented by the two case studies (bold black boundaries) embedded in their natural biome type and current anthrome (Ellis et al. 2010).

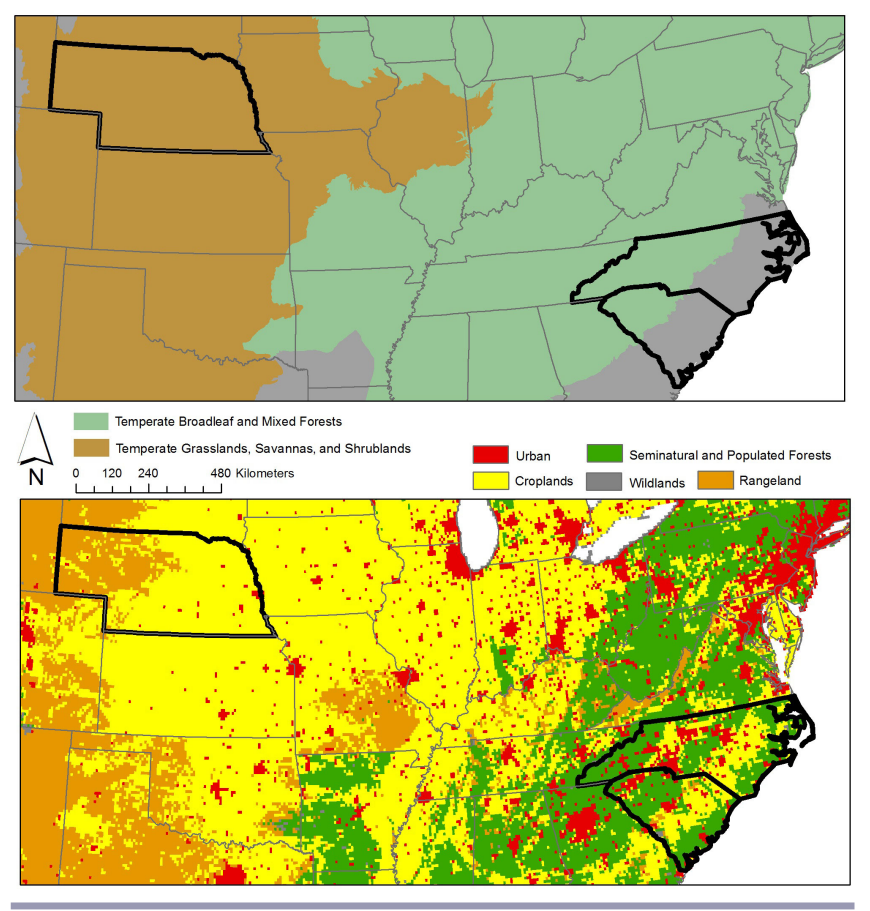

Forests in the western Carolinas fall within the Blue Ridge and Piedmont ecoregions. Blue Ridge forests range in area, provide habitat for a diversity of species, and are thought to be important hotspots for resiliency in the face of climate change (Anderson et al. 2014). Despite recent land use change, some large contiguous forest blocks and old-growth patches remain, in part because of steeper terrain and complex topography, which is less suitable for logging. Downslope, the forests in the Piedmont region largely comprise small isolated patches of deciduous, mixed, and pine forests. As in the Blue Ridge forests, species found in these forest patches are diverse (Hunter et al. 2002, Pimm et al. 2014). For simplicity in the case study, we focus on two birds; Golden-winged Warbler (Vermivora chrysoptera) and Brown-headed Nuthatch (Sitta pusilla), both species of conservation concern (Partners in Flight 2012). The Brown-headed Nuthatch has declined at a rate of $0.54 \%$ per year in the last half-century (Sauer et al. 2014). A pine specialist (Withgott and Smith 1998), the nuthatch was traditionally thought to prefer large mature stands of pine. Golden-winged Warblers have declined at a steeper rate of $2.6 \%$ per year (Sauer et al. 2014). A neotropical migrant, the southernmost extent of their breeding range reaches western North Carolina and they primarily favor scrubby, earlysuccessional habitat at elevations above $600 \mathrm{~m}(2000 \mathrm{ft}$.) for breeding (Confer 1992). For both species, fragmentation of remaining habitat patches creates significant complications because sustained abundance is spatially determined by factors like movement, dispersal, and resource availability (Driscoll et al. 2013). Successful conservation of these species is clearly dependent on outcomes of private land management decisions in Blue Ridge and Piedmont forests. 
Case study \#2: Agroecosystems in the Midwest and Great Plains The second natural system we consider is agricultural land, in particular row crop agriculture that has replaced temperate grasslands and shrublands of the Midwestern U.S. (Fig. 2). Like temperate forests, grasslands, savannas, and shrublands have declined in area by $45 \%$ with only $4.6 \%$ protected (Hoekstra et al. 2005). As an anthrome, croplands are $15 \%$ of ice-free surface but only $7 \%$ of protected areas (Martin et al. 2014). Both the loss of natural habitat and the intensification of existing agricultural systems are resulting in declining biodiversity across farming types and regions (Krebs et al. 1999, Johnson et al. 2011). The predominance of agriculture as a land use and the need to sustain food for human populations necessitate conservation solutions for habitats embedded in productive farm systems.

The clear evidence of agriculture's negative effects on biodiversity and perceived homogeneity of agroecosystems might suggest a relative clarity for conservation, a perception perhaps best exemplified by the argument for land sparing (Green et al. 2005), where ecosystems are subdivided into native lands (or natural systems) and farmland (or the human system), with little interaction between systems (Fischer et al. 2008). Despite the evidence presented for land sparing, conservation in agricultural ecosystems requires a careful examination of the interactions between human and natural subsystems across scales (Balmford et al. 2012, Fischer et al. 2014). Framing conservation on agricultural lands as a CHANS better aligns with land sharing (Fischer et al. 2008), which acknowledges and capitalizes on the linkages between farming and nature.

One well-developed practice reflecting the principles of land sharing is agroforestry, or working trees embedded in different agricultural landscapes. Hedgerows, windbreaks, fence lines and field edges, silvopasture, and other woody vegetation are examples of agroforestry found in agroecosystems. These examples of planned diversity (Matson et al. 1997) provide environmental benefits including mitigation of climate change (Schoeneberger 2009), regulation of nonpoint source pollution (Udawatta et al. 2011), and provisioning of habitat for native pollinator and wildlife species (Mize et al. 2008, Batáry et al. 2011, Quinn et al. 2014). This case study draws upon wildlife conservation efforts in the eastern half of Nebraska via woody cover in the extensive and intensive agricultural systems emblematic of the Midwestern United States. Although grassland birds are traditionally the focus of the region, recent work has focused on the conservation value of woody cover for resident and migratory birds (e.g., Puckett et al. 2009, Quinn et al. 2014). One species of particular interest is the Bell's Vireo (Vireo bellii), a Tier One species of conservation concern under the Nebraska Legacy Project. The Bell's Vireo is a shrub-nesting species whose populations have declined $0.98 \%$ annually in the central U.S. since 1966 (Sauer et al. 2014). Unlike many grassland species, this vireo represents a scalable conservation opportunity on farmland with a low opportunity cost to farmers (Gunton et al. 2016).

\section{HUMAN SUBSYSTEMS}

The above discussion of natural subsystems reflects the traditional focus of wildlife management and biodiversity conservation. The breadth of research focused on natural systems would suggest that conservation biology is able to recognize and suggest solutions to practitioners. However, translation of conservation research to practice involves understanding motivations, attitudes, and external controls of human systems (e.g., Quinn and Burbach 2008). Thus, the subsequent step in CHANS-thinking is adding the human systems (Fig. 1) to conservation planning and practice.

Case study \#1: Conservation easements in the western Carolinas Conservation easements are a management tool, most often employed by private entities, to preserve land for natural value or historical, personal, or economic reasons (Wallace et al. 2008, Rissman 2013). Human systems associated with easements (Fig. 1) include landowners, land trusts, regional and national institutions and actors, and the legal terms of the easement itself. Though conservation easements are a local system and reflect individual-level decisions, they are embedded within larger human subsystems.

Land use change in the western Carolinas is driven by a growing population and urban development (Terando et al. 2014) and a demand for woody biofuels (Johansson and Azar 2007). In the Blue Ridge ecoregion, high-elevation development is responsible for loss of habitat, particularly because good habitat is also desirable for homes with a view. Likewise, suburban development in the Piedmont ecoregion of South Carolina is driving forest loss and land use change. This latter ecoregion falls within the center of the rapidly developing Southern Megalopolis (Terando et al. 2014) where population is expected to increase by over $100 \%$ by 2050, resulting in greater urban development and continued stress on existing forest patches. Because of these increasing pressures on the land, and limited resources of county, state, and federal landholders, tools are needed for planning beyond the actions of government and particularly ones that involve private landowners.

Conservation easements are legally binding agreements that outline prohibited activities, i.e., "negative language covenants," and reserved rights of the grantors, but do not transfer away ownership of the land. Importantly, easements do not exist to mandate affirmative actions for the landowner, but rather outline which future development or management rights have been given up by the landowner (Rissman 2013). The easement holder (a land trust or sometimes a government agency) works with the landowner to ensure compliance with these covenants and thus protect local ecosystems and their associated benefits for current and future users. Land trusts, organizations tasked with easement oversight and stewardship across a large spatial scale, preserve the land indefinitely. In total, U.S. land trusts conserve over 19 million hectares (47 million acres, Land Trust Alliance 2010). Over 37,600 and 19,800 hectares (93,000 and 49,000 acres) are held in the Blue Ridge and Piedmont, respectively (NCED 2015).

Both individual landowners and land trusts affect conservation on private land. Decisions about future use and development of land, in the context of drafting easements, are complicated and influenced by economic and personal factors. It is important, though challenging, to recognize human motivations in such processes. Indeed, Monticino et al. (2007) speak to the difficulty of quantifying and predicting factors like "tradition value" to property owners. Likewise, the process of negotiating a conservation easement is arduous and sometimes contentious, requiring an investment of time, financial capital, legal background work, documentation of the property, and 
negotiations among parties about reserved rights. Accounting for human/social variables (motivations, attitudes, external controls) is highly important for successful land conservation transactions. Land trusts, too, can directly influence decision making on a particular conservation easement property, though the amount to which they pursue specific conservation objectives varies (Dayer et al. 2016). Some land trusts interact more deliberately with landowners, presenting management practices that benefit a species of conservation concern, which may or may not be facilitated by the landowner. However, the conservation goals of land trusts may not be as specific or intentional and thus not as useful as they have the capacity to be if systems, objectives, and goals were better aligned (Dayer et al. 2016).

Land trusts frequently make decisions at a landscape or regional scale, beyond the individual parcel subject to an easement. Because of limited funds and stewardship capacity, land trusts have to make strategic decisions about which properties to protect within a given landscape, creating heterogeneity in the spatial arrangement of easements and conservation success on the ground. Understanding natural systems aids land protection prioritization, but the human factor is critical in decision making and its outcomes. For example, the appeal of a particular region may drive a land trust's efforts more than species conservation if its resources are limited and public appeal translates into more funding.

Other human subsystems directly and indirectly affect conservation via easements at regional and national scales, including governmental, nonprofit, and other private institutions. For example, organizing bodies exist to make land trusts more effective across a larger scale. In the United States, the Land Trust Alliance is a national organization that approves accreditation of individual trusts, assuring prospective partners that these land trusts abide by defined standards and policies. Government representatives may step in to uphold ordinances and regulations at the local, state, or federal level. State funds are often drawn upon to help promote land conservation projects in both states (e.g., South Carolina Conservation Bank, North Carolina Clean Water Management Trust Fund). Federal programs and grants provide essential funding for some land transactions (e.g., United States Department of Agriculture, Land and Water Conservation Fund) and stewardship objectives (e.g., United States Fish and Wildlife Service).

Case study \#2: Agroecosystems in the Midwest and Great Plains Like conservation easements, conservation in agroecosystems reflects multiple scales of human subsystems. Though the case study focuses on the primary scale of decision making, i.e., the farm, decisions reflect regional and global drivers and interacting institutions and actors. Farmers manage almost $40 \%$ of terrestrial ice-free surface, but their decisions are influenced by individual consumer food choices through local, national, and international food policy. A growing world population, a demand for biofuels, and changing diets are increasing pressure on existing agricultural land and the humans who manage these systems. Given the extent and competing demands for farmland, understanding the linked human systems is essential to optimize trade-offs.

At a local scale, farmers are the primary decision makers of land they own and rent. Their first priority is biomass or food production (Balmford et al. 2012). Conservation goals are thus a secondary priority (unlike easements discussed in the case study above) and most conservation decisions consider opportunity costs. Furthermore, a farmer's attitude toward conservation and subsequent likelihood of adopting proenvironmental practices is influenced by multiple social factors and external controls, e.g., family history, policy, land ownership, farm location (Quinn and Burbach 2008). For example, ownership patterns can influence implementation of conservation practices when motivations and incentives for conservation differ for renters or absentee landowners as compared to individuals owning and living on the land (Soule et al. 2000).

Beyond the farm, choices emerge from a network of systems that have varied perceptions, perspectives, and motivations regarding conservation. These include state and federal agencies, a diversity of farming nongovernmental organizations (NGOs) with varied perspectives, and conservation groups that may have competing goals. Farm policy is one important external control, setting funding priorities at local and national levels and articulating best management practices. In the United States the Farm Bill, like the European Union Common Agricultural Policy, sets national conservation priorities for farmland and distributes funds to farmers. In the U.S., state and university outreach (e.g., Brandle and Finch 1991) and the federal Natural Resource Conservation Service (NRCS) provide advice and the latter provides funding for the adoption of conservation practices like windbreaks on individual farms. Consumers are an additional important but indirect component of these subsystems. Consumer preferences create demand for specific products and for particular production methods, like organic farming. Lastly, as Wendell Berry notes (Imhoff and Baumgartner 2006:5), "Why should conservationists have a positive interest in, for example, farming? There are lots of reasons, but the plainest is: Conservationists eat."

This case study builds on collaborative work between farmers, researchers, and conservationists. Researchers from the University of Nebraska Lincoln partnered with the Nebraska Sustainable Agriculture Society (NSAS) and Nebraska Forest Service to obtain funding, via a capacity building grant, to improve success and adoption of conservation practices associated with agroforestry systems in eastern Nebraska (Fig. 2). Funding for this grant from the Nebraska Bird Conservation Partnership allowed for an exchange of information between systems, including private, state, and federal farming conservation organizations, increasing awareness of the importance of conservation on private farmland. This cross-institution and cross-discipline collaboration was beneficial in that it forced each group, or subsystem, to articulate its needs and find common ground with the other groups. In this relationship, farmers, via NSAS, shared with researchers what conservation questions they most wanted answered. Likewise, university researchers were able to better frame their research questions to reflect conservation practices that farmers would be more likely to adopt.

\section{CHANS ELEMENTS AND INTERACTIONS}

Identification of relevant subsystems (Fig. 1) helps understand institutions and actors that play a role in biodiversity conservation on private lands (e.g., Turner et al. 2003, Carter et al. 2014). However, as shown above, subsystems do not work in isolation and just describing systems is insufficient to understand conservation opportunities and costs. The CHANS framework 
provides a model to understand the interactions between human and natural systems, environmental and social concerns, disciplines, and scales of action. Recognizing and understanding these elements and interactions is essential to successful and sustainable conservation. Below we discuss specific CHANS elements and interactions individually, as they relate to our case studies, to better illustrate how they function within the contexts of the systems discussed above. Through this process, it becomes clear that framing a perceived isolated element in the CHANS framework often reveals an unidentified interaction with another element. Furthermore, an awareness of connections between elements and interactions allows researchers, practitioners, and stakeholders to better evaluate trade-offs and compromises when making decisions on private lands.

We start with the idea of scale, building on different scales of the human and natural subsystems across elements and interactions. Next we discuss how heterogeneity, feedbacks, time lags and legacy effects, nonlinear dynamics with thresholds, and surprises function in our example regions to affect research, planning, and practice on private lands.

\section{Scale}

Although it is widely agreed that there is no correct scale at which to work (Levin 1992), there is agreement that consideration of larger scales is necessary for successful conservation (Fahrig 2001). However, on private lands, a disconnect between scales of the human system (land ownership) and the natural system (species habitat requirements) can create challenges to conservation on private land. Though there are cases, e.g., western U.S., Patagonia, where one individual owns extensive lands, the spatial extent of management of any one private landowner is most often limited. Conservation objectives should therefore align with available resources. Given the complexity at the interface of human and natural systems, the question of how to expand the scale of conservation application, e.g., more easements, proximity to protected lands, or increased matrix quality, remains uncertain. Species conservation on private lands thus first requires identification of suitable practices that can be adopted by individual landowners. Then, beyond-the-parcel efforts should consider coordination between landowners to protect suitably large tracts of land (Powell 2012, McKenzie et al. 2013) and consider how the matrix type around a unit of land is managed because it has become clear that the larger matrix surrounding a patch is a significant modifier of local conservation success (Fahrig 2001).

Two of the species highlighted in the case studies represent conservation opportunities that can be captured at smaller scales: the scale of a single habitat patch. Greater patch size, but not greater cumulative pine habitat on the landscape, is an important driver of Brown-headed Nuthatch abundance patch (Wood and Quinn 2016). Thus, interested private landowners can maintain and re-establish pine stands on their property regardless of their location on the urban-rural gradient or proximity to other forest patches. Likewise, Bell's Vireo abundance and daily nest survival are influenced by both crop and noncrop land use patterns within and immediately adjacent to a farm (Quinn et al. 2014; Quinn, unpublished data), including woody vegetation adjacent to crop fields.
When conservation is not possible at local scales (a single easement or farm), planning and strategic partnerships between agencies and organizations can help create an opportunity for success. In the Highlands of Roan, whose grassy balds are wellsuited to Golden-winged Warbler habitat restoration, land trusts and conservation groups, e.g., Southern Appalachian Highlands Conservancy and Appalachian Trail Conservancy, protect and manage many contiguous tracts of land. In this way, private institutions help provide connectivity between available breeding habitat by complementing the U.S. Forest Service's limited land ownership. These efforts require that multiple stakeholders across human systems be engaged in the creation and execution of conservation plans. Planning at a regional or even county level helps to align the scales of human and natural systems and find strategic solutions that benefit both.

\section{Social-ecological heterogeneity}

Heterogeneity across natural systems reflects natural land cover change, disturbance, and anthropogenic land use change. Likewise, in human subsystems, heterogeneity exists as a function of variation in individuals, policy, political and social philosophy, socioeconomic incentives, institution legacies, and population demographics and growth rates. Individual and regional preferences for habitat types create different and shifting management goals, just as landscape heterogeneity reflects current and historical land use.

The value of landscape heterogeneity at local and landscape scales as a conservation target in agroecosystems has been demonstrated in multiple contexts (Farhig et al. 2011, Pickett and Siriwardena 2011, Quinn et al. 2014). Indeed, habitat heterogeneity is a key element of land sharing (Fisher et al. 2008). Agroforestry practices, including windbreak systems, hedgerows, field buffers, and fruit trees create heterogeneity while providing environmental and economic value to the farm. In eastern Nebraska, agroforestry creates habitat for the Bell's Vireo and other shrubland birds (Quinn et al. 2014). The same practices may, however, come at a cost as other species of equal conservation priority require a large area without trees and do not benefit from habitat heterogeneity (Quinn et al. 2012).

The specific terms of an easement, land use and landowner history, and natural and socioeconomic conditions create heterogeneity in the regional distribution (Baldwin and Leonard 2015) and in a land trust's portfolio of easements. Managing across this social and natural heterogeneity is challenging. Options negotiated in specific easements vary dramatically based on the conservation priorities at the time and place when the easement was negotiated and the priorities of the landowner (Wallace et al. 2008, Rissman 2013). Some easements include the right to harvest timber or clear specified habitat while others prohibit any such activities to maximize conservation objectives. Choices made over time on the land create heterogeneity as well as time lags and legacy effects. Heterogeneity in different economic and ecological values challenges a land trust that must manage for multiple conservation objectives across landowners and landscapes. For example, in the western Carolinas there are over 390 reported easements protecting over 44,515 hectares (110,000 acres) that vary in landscape resilience, connectivity, and diversity (Fig. 3; Anderson et al. 2014, NCED 2015). Easements in flagship ecosystems with high ecological value, such as the Blue 
Fig. 3. Distribution of conservation easements (black outline) in the Southern Piedmont and Blue Ridge regions of North and South Carolina across (A) anthrome types (Ellis et al. 2010), (B) landscape diversity, (C) landscape resilience, and (D) landscape connectedness (Anderson et al. 2014).
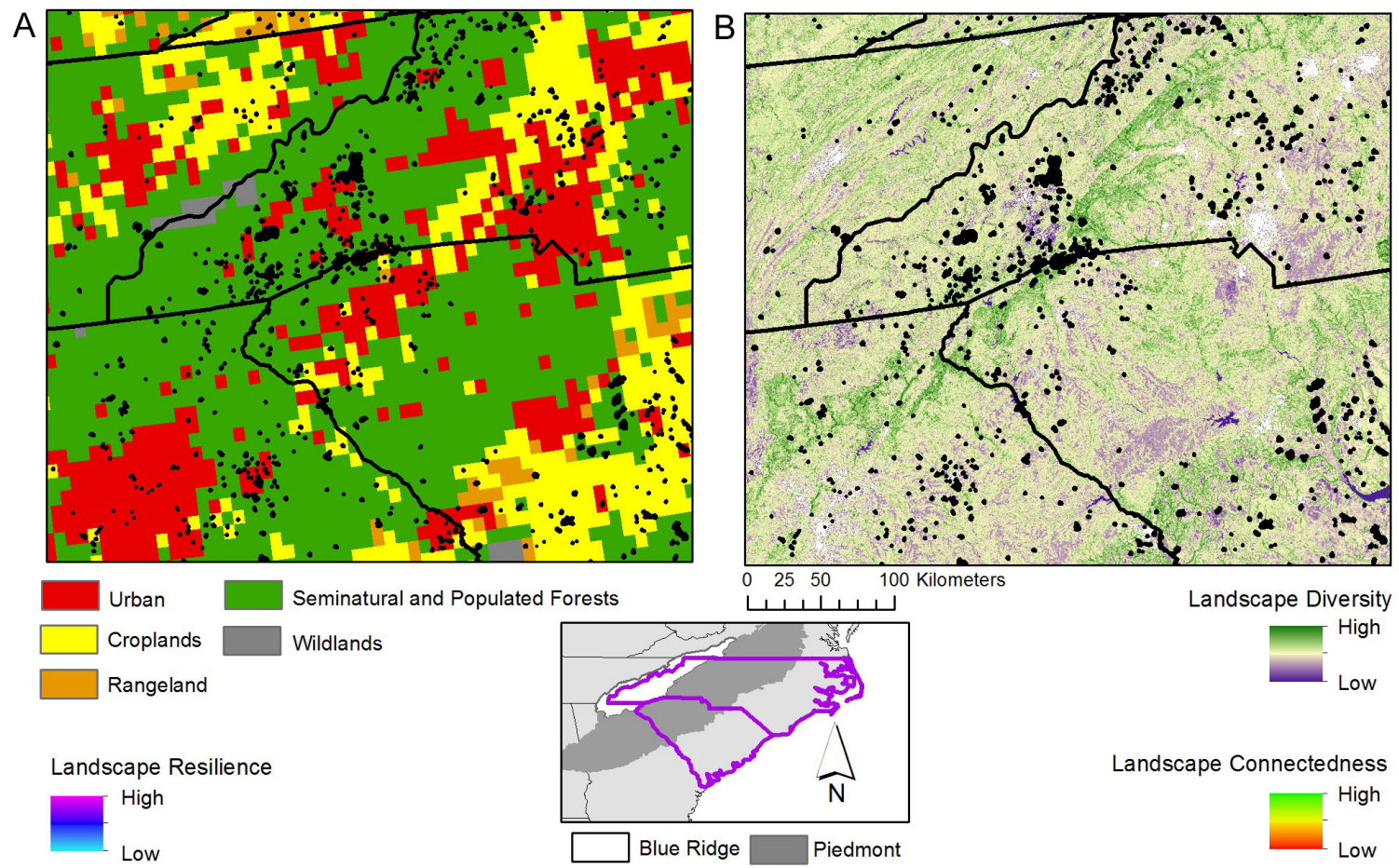

Wildlands

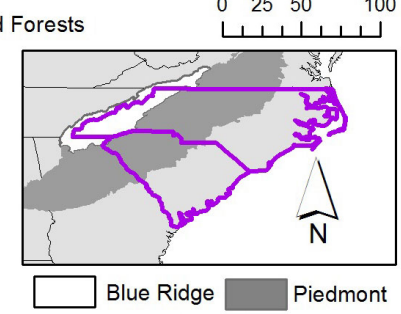

Landscape Connectedness
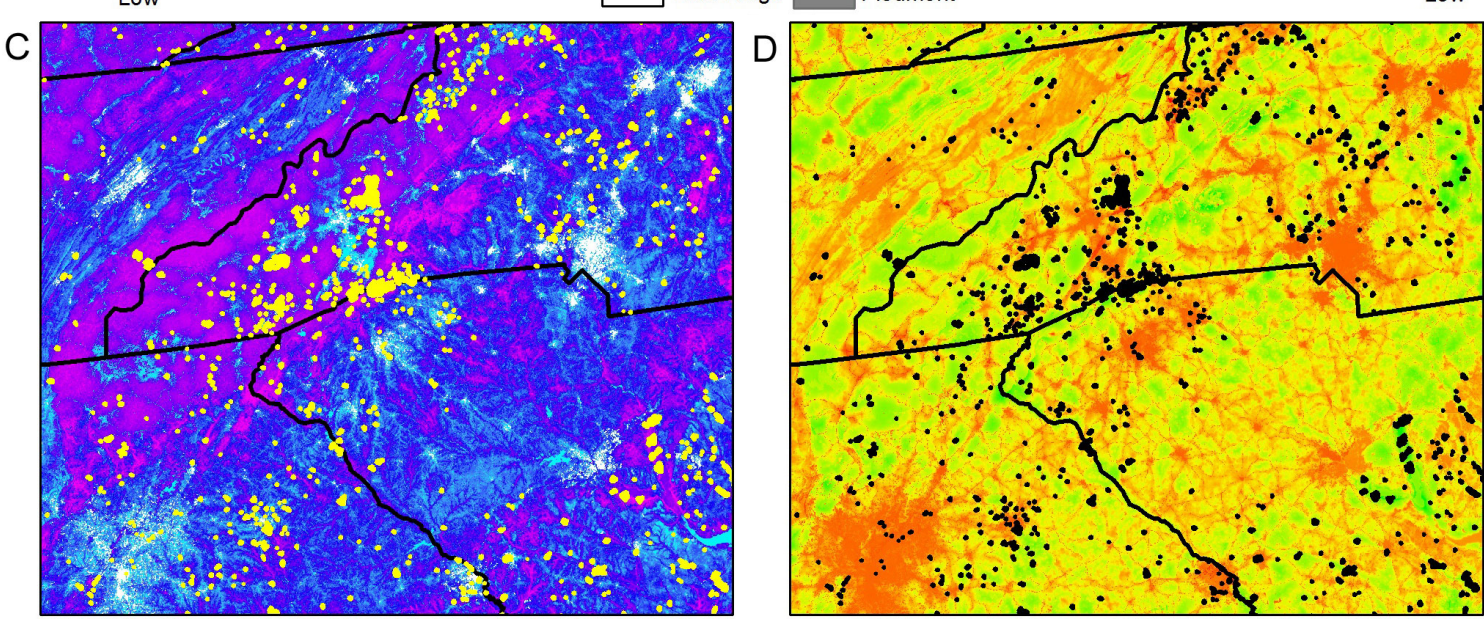

Ridge Mountains or the Highlands of Roan, appeal to human values and create support for conservation. Yet, a land trust will also hold easements and monitor other parcels not embedded in one of these prioritized landscapes or in areas with low connectivity or landscape diversity. Likewise, only subsets of these easements have the necessary natural systems to warrant habitat creation/restoration for targeted species, e.g., Golden-winged Warbler, Brown-headed Nuthatch. Communication of this variation is an essential part of the relationship between the landowner and the land trust.

\section{Feedback loops}

Consideration of feedback loops built through relationships can enhance the conservation impact of private landowners and leverage small investments for continued future successes. When an easement or conservation action on farmland benefits the local landowner, their willingness to continue or motivation to maintain and improve the local ecosystem may increase. As a consequence, local conservation groups, e.g., North Carolina Audubon Society for Golden-winged Warbler or Nebraska Forest Service for agroforestry practices, may offer cost-share incentives to maintain and increase habitat. The landowner benefits by receiving positive reinforcement, e.g., praise of their success among peers, increased property value, eligibility for more funding and support from broader institutions, which may promote the landowner's willingness to increase the scale of their commitment to stewardship. At the same time, a land trust or other conservation institution, private or public, benefits by 
increased spatial extent of land managed for a threatened species, which might open up further funding or additional and complementary conservation objectives. Ultimately, this effort returns back to the scale of the individual when regional successes recruit new land owners.

These feedbacks within local management can connect with society more broadly (Brashares et al. 2014). A decision by a private landowner to limit building rights on a high-elevation ridge property will provide a benefit to the general public (the aesthetic values and scenic beauty of undeveloped land or sustainable agricultural systems) or a farmer's decision to include a forest buffer would improve water quality downstream, reducing water treatment costs. Economic incentives and disincentives to the landowner encourage individuals to continue to provide these public benefits. Payment for ecosystem services, e.g., conservation payments in agriculture, and tourism are becoming more widely acknowledged as important illustrations of feedback mechanisms in terms of human behavior and conservation (Tallis et al. 2008, Allen 2015). When successful, mutually beneficial relationships will feedback between local and regional subsystems, increasing the extent and impact of conservation efforts. Taking feedbacks into account improves the likelihood of conservation success because the demonstration of positive outcomes helps when investing limited funds and building regional support. Making these indirect outcomes clear to the general public can build support and justification for single land conservation projects.

Although not discussed here, negative feedbacks can occur when conservation priorities are not achievable on a single property and when, despite individual landowner efforts, no gains are seen. This can discourage future efforts. Land protection for particular management objectives has to be strategic and targeted. Ultimately, looking for feedback loops can aid researchers, planners, and practitioners in successfully understanding and taking advantage of conservation opportunities.

Time lags/legacy effects of past couplings on future possibilities Recognition of temporal variation is key in research, planning, and practice (Ramalho and Hobbs 2012). Lag times between human-natural system interactions and their socioeconomic or ecological consequences introduce complexity to landscape conservation planning (Liu et al. 2007) and can make it more difficult to predict future change based on past trends alone. The natural systems of our case studies have shifted rapidly, but conservation priorities, actions, or perceptions may reflect legacy rather than reality. For instance, although temperate forests of the southeast United States were replaced by agriculture during the 20th century, today forested landscapes are being lost to rapid urbanization, a more recent threat (Terando et al. 2014). Likewise, decisions made during the late 1800 s to convert native prairie to cropland across the Midwest, shifting it from a grassland biome or wild anthrome with low levels of human populations and land cover change to a cropland anthrome with little native habitat (Ellis et al. 2010), dictate the scope of current conservation options on private land in the Midwest (Quinn et al. 2014).

At a local scale, management options are controlled by past landowner decisions and influenced by tradition (Monticino et al.2007). Family tradition or historical success of an economically centered land use (agriculture, surface mining, logging) may discourage proenvironmental behaviors, e.g., windbreaks and conservation easements limiting impactful land uses, but past and present landowners also experience unequal payoffs for a property's ecosystem services. For instance, it can take decades for timber stands to be ready for reharvesting and the full benefits to the farmer and wildlife of a windbreak can take one generation to emerge. Current landowners may be influenced negatively by previous managers' or landowners' decisions because they deal in the present with negative lag effects such as erosion from poorly executed timber extractions or poor soil management, e.g., removal of terraces. The permanence of easements adds an interesting element of future time lags. Individual easement terms, based on the original landowners' objectives, will determine if variation occurs on particular properties over time, dictating the extent of future land use scenarios. Although the permanent temporal scale of a conservation easement may be appealing, the same permanence may limit future value because fixed boundaries limit the ability of an individual easement to adapt to or provide benefits under future climate change (Rissman et al. 2015). These examples of temporal effects creating challenges and opportunities for conservation efforts further illustrate how interconnected elements of CHANS are, as they also relate to feedbacks, nonlinear dynamics, and scale within and between the human and natural subsystems.

\section{Nonlinear dynamics with thresholds}

Identification of nonlinear responses in natural systems to loss or restoration may be some of the most critical pieces of information communicated between human systems. Identifying important ecosystem and habitat features, and their effects on biodiversity conservation, are key to developing models that can help leverage funds strategically. When resources or economic conditions limit options, in particular the spatial extent of contiguous land for conservation, identification of minimum thresholds can prevent investment in conservation at too small a scale to be effective. Private landowners interested in contributing to species conservation efforts would benefit from using data on minimum patch area (e.g., Bayard and Elphick 2010) to determine if conservation is warranted. Our data on Bell's Vireo suggest that embedding small patches of Rough-leaf Dogwood (Cornus drummondii) in heterogeneous farm systems can have an outsized benefit to conservation of the species with very little, if any, opportunity costs to the farmer. However, conservation of grassland species in this same region requires larger areas with minimum patches of 25-100 hectares depending on the species (Helzer and Jelinski 1999). Likewise, in the southeast U.S., interested landowners who are unsure if they have suitable habitat for Golden-winged Warblers can utilize thresholds based on the configuration of their management sites; a minimum size of 2 hectares ( 5 acres) of habitat can be created if the patch is within 300 meters ( 1000 feet) of existing breeding habitat, while those over that distance should aim to create approximately 10 hectares (25 acres) of habitat (Golden-winged Warbler Working Group 2013). Given that an easement cannot be placed on every parcel and farmers cannot set aside all their land for species conservation, knowing thresholds of success can prevent a feedback where negative outcomes of ineffective efforts sours future conservation efforts.

\section{Surprises}

Examination of coupled human and natural systems reveals unexpected or unaccounted for conservation opportunities and 
challenges. Rare species discovered through annual monitoring or biological inventories on small patches of private lands can challenge conservation norms that prioritize large-scale protection. Indeed, the growing literature on conservation successes in human systems is full of surprises (Martin et al. 2014) where traditional conservation practice has focused on the pristine and untouched rather than on conservation opportunities within human-shaped ecosystems. For example, it was unexpected that the threatened Brown-headed Nuthatch was more abundant in pine patches embedded within residential developed land in the Piedmont than in patches embedded within rural or forested land use types (Wood and Quinn 2016). This surprise should be seen as a conservation opportunity given that suitable habitat is not always indicated by an undisturbed, large contiguous tract of pristine or native habitat disconnected from human systems. A conservative approach to easements may result in land trusts that only accept conservation easements in intact natural ecosystems, which might exclude suitable habitat for threatened species within suburban or agricultural landscapes. Likewise, conservation groups working in cropland anthromes would be remiss to not reach out to farmers to identify conservation opportunities in cropland anthromes, particularly given the bundled ecosystem service benefits of agroforestry.

The intricacy of human systems can also cause surprise. Exactly who decides to participate in land acquisition for conservation, and why, is complex. It is within the power of a single private actor or stakeholder to make surprising strategic decisions in rapidly developing regions. For example, highly motivated individuals with financial capital can make a large difference, as evidenced by philanthropists and "conservation realtors" in North Carolina who make land purchases with no intention of development when land trusts cannot afford to do so. Conservation groups may not be able to identify these individuals beforehand, but the impact of those individuals should be celebrated and shared so that others may be motivated to take similar actions. Lastly, surprises are not always positive. It may surprise a landowner to learn that a land trust is not interested in his or her land because of its limited ecological value, or to realize that unanticipated changes in market values of crops may create unexpected changes in the extent and effect of successful conservation programs. The latter point is perhaps best observed in the decline in Conservation Reserve Program lands following the rise in crop prices in the late 2000s.

\section{CONCLUSION}

Analyses of biodiversity conservation efforts on private lands benefit from consideration as a coupled human and natural system. Our formal synthesis of recent conservation actions under the CHANS framework illustrates new relationships and interactions that may not have been identified in previous analyses. Here the intersection of conservation research and practice, i.e., what lands are protected, how they are protected, why they are protected, clearly demonstrates coupling between systems. The application of CHANS thinking to our case studies suggests how multiple institutions will frame conservation priorities and how the interactions between institutions and priorities will create challenges and opportunities reflecting past, current, and future controls. In the eastern U.S., we see how coordination between private landowners and nonprofit conservation organizations can leverage resources for land protection and management. In the Midwest, we see that desire for conservation solutions at local scales can unite individuals and agencies to find common ground via agroforestry. Formalizing the process organizes the subsystems and their interactions in a way that allows for better and more thorough research, planning, and practice going forward.

As traditional conservation goals align with priorities of human systems (public health, urban planning, agriculture), providing a framework for individuals working on private land to work within will make it easier for conservation biology, as a field, to align with complementary goals of sustainability science. To move forward in creating a sustainable planet, we must remain under critical environmental thresholds while simultaneously addressing social foundations for all people (Raworth 2012). On private lands, engaging institutions and actors of human subsystems in a conservation outcome will help ensure multiple strategies for conservation success. New economic drivers, population change, and land management legacies will continue to affect the reality of conservation. The immense difficulty of this task requires communication between disciplines and among varied institutions and actors, especially those managing private lands. The CHANS framework provides a model for research and dialogue that bridges environmental and social concerns, disciplines, and scales of action.

Responses to this article can be read online at: http://www.ecologyandsociety.org/issues/responses. $\mathrm{php} / 9132$

\section{Acknowledgments:}

For useful comments on the manuscript we thank J. Smith, C. Wood, the editors, and two anonymous reviewers. We thank $H$. Bahal for her assistance with Figure 1. We thank Furman Advantage, the David E. Shi Center for Sustainability, and the Nebraska Bird Conservation Partnership for support.

\section{LITERATURE CITED}

Agarwala, M., G. Atkinson, B. P. Fry, K. Homewood, S. Mourato, J. M. Rowcliffe, G. Wallace, and E. Milner-Gulland. 2014. Assessing the relationship between human well-being and ecosystem services: a review of frameworks. Conservation and Society 12(4):437-449. http://dx.doi.org/10.4103/0972-4923.155592

Allen, K. E. 2015. Trade-offs in nature tourism: contrasting parcel-level decisions with landscape conservation planning. Ecology and Society 20(1):21. http://dx.doi.org/10.5751/ es-07058-200121

Anderson, M. G., M. Clark, and A. O. Sheldon. 2014. Estimating climate resilience for conservation across geophysical settings. Conservation Biology 28(4):959-970. http://dx.doi.org/10.1111/ cobi. 12272

Baldwin, R. F., and P. B Leonard. 2015. Interacting social and environmental predictors for the spatial distribution of conservation lands. PLOS ONE 10(10):e0140540. http://dx.doi. org/10.1371/journal.pone.0140540 
Balmford, A., R. Green, and B. Phalan. 2012. What conservationists need to know about farming. Proceedings of the Royal Society B: Biological Sciences 279:2714-2724. http://dx.doi. org/10.1098/rspb.2012.0515

Batáry, P., A. Baldi, D. Kleijn, and T. Tscharntke. 2011. Landscape-moderated biodiversity effects of agri-environmental management: a meta-analysis. Proceedings of the Royal Society B: Biological Sciences 278(1713):1894-1902. http://dx.doi. org/10.1098/rspb.2010.1923

Bayard, T. S., and C. S. Elphick. 2010. How area sensitivity in birds is studied. Conservation Biology 24(4):938-947. http://dx. doi.org/10.1111/j.1523-1739.2010.01480.x

Brandle, J. R., and S. Finch. 1991. How windbreaks work. Historical materials from University of Nebraska-Lincoln Extension. EC91-1763-B. Lincoln, Nebraska, USA. [online] URL: http://digitalcommons.unl.edu/extensionhist/4709

Brashares, J. S., B. Abrahms, K. J. Fiorella, C. D. Golden, C. E. Hojnowski, R. A. Marsh, D. J. McCauley, T. A. Nuñez, K. Seto, and L. Withey. 2014. Wildlife decline and social conflict. Science 345(6195):376-378. http://dx.doi.org/10.1126/science.1256734

Callicott, J. B., R. Rozzi, L. Delgado, M. Monticino, M. Acevedo, and P. Harcombe. 2007. Biocomplexity and conservation of biodiversity hotspots: three case studies from the Americas. Philosophical Transactions of the Royal Society of London B: Biological Sciences 362(1478):321-333. http://dx.doi.org/10.1098/ rstb.2006.1989

Carter, N. H., A. Viña, V. Hull, W. J. McConnell, W. Axinn, D. Ghimire, and J. Liu. 2014. Coupled human and natural systems approach to wildlife research and conservation. Ecology and Society 19(3):43. http://dx.doi.org/10.5751/es-06881-190343

Confer, J. 1992. Golden-winged Warbler (Vermivora chrysoptera). No. 20 in A. Poole, editor. The birds of North America. Cornell Lab of Ornithology, Ithaca, New York, USA. http://dx.doi. org/10.2173/bna. 20

Dayer, A. A., A. D. Rodewald, R. C. Stedman, E. A. Cosbar, and E. M. Wood. 2016. Wildlife conservation and private protected areas: the discrepancy between land trust mission statements and their perceptions. Environmental Management 58(2):359-364. http://dx.doi.org/10.1007/s00267-016-0713-3

Driscoll, D. A., S. C. Banks, P. S. Barton, D. B. Lindenmayer, and A. L. Smith. 2013. Conceptual domain of the matrix in fragmented landscapes. Trends in Ecology \& Evolution 28 (10):605-613. http://dx.doi.org/10.1016/j.tree.2013.06.010

Drummond, M. A., and T. R. Loveland. 2010. Land-use pressure and a transition to forest-cover loss in the eastern United States. Bioscience 60(4):286-298. http://dx.doi.org/10.1525/bio.2010.60.4.7

Ellis, E. C., K. Klein Goldewijk, S. Siebert, D. Lightman, and N. Ramankutty. 2010. Anthropogenic transformation of the biomes, 1700 to 2000. Global Ecology and Biogeography 19(5):589-606. http://dx.doi.org/10.1111/j.1466-8238.2010.00540.x

Ellis, E. C., and N. Ramankutty. 2008. Putting people in the map: anthropogenic biomes of the world. Frontiers in Ecology and the Environment 6(8):439-447. http://dx.doi.org/10.1890/070062
Fahrig, L. 2001. How much habitat is enough? Biological Conservation 100(1):65-74. http://dx.doi.org/10.1016/S0006-3207 (00)00208-1

Fahrig, L., J. Baudry, L. Brotons, F. G. Burel, T. O. Crist, R. J. Fuller, C. Sirami, G. M. Siriwardena, and J.-L. Martin. 2011. Functional landscape heterogeneity and animal biodiversity in agricultural landscapes. Ecology Letters 14(2):101-112. http://dx. doi.org/10.1111/j.1461-0248.2010.01559.x

Fan, P., Y. Xie, J. Qi, J. Chen, and H. Huang. 2014. Vulnerability of a coupled natural and human system in a changing environment: dynamics of Lanzhou's urban landscape. Landscape Ecology 29(10):1709-1723. http://dx.doi.org/10.1007/ s10980-014-0061-8

Fiksel, J. 2006. Sustainability and resilience: toward a systems approach. Sustainability: Science, Practice \& Policy 2(2):14-21.

Fischer, J., D. J. Abson, V. Butsic, M. J. Chappell, J. Ekroos, J. Hanspach, T. Kuemmerle, H. G. Smith, and H. von Wehrden. 2014. Land sparing versus land sharing: moving forward. Conservation Letters 7(3):149-157. http://dx.doi.org/10.1111/ conl.12084

Fischer, J., B. Brosi, G. C. Daily, P. R. Ehrlich, R. Goldman, J. Goldstein, D. B. Lindenmayer, A. D. Manning, H. A. Mooney, L. Pejchar, J. Ranganathan, and H. Tallis. 2008. Should agricultural policies encourage land sparing or wildlife-friendly farming? Frontiers in Ecology and the Environment 6(7):380-385. http://dx.doi.org/10.1890/070019

Golden-winged Warbler Working Group. 2013. Best management practices for Golden-winged Warbler habitats in the Appalachian region. Golden-winged Warbler Working Group. [online] URL: http://www.gwwa.org/resources/GWWA-APPLRegionalGuide 130808 lores1.pdf

Green, R. E., S. J. Cornell, J. P. W. Scharlemann, and A. Balmford. 2005. Farming and the fate of wild nature. Science 307 (5709):550-555. http://dx.doi.org/10.1126/science.1106049

Gunton, R. M., L. G. Firbank, A. Inman, and D. M. Winter. 2016. How scalable is sustainable intensification? Nature Plants 2:16065. http://dx.doi.org/10.1038/nplants.2016.65

Helzer, C. J., and D. E. Jelinski. 1999. The relative importance of patch area and perimeter-area ratio to grassland breeding birds. Ecological Applications 9(4):1448-1458.

Hoekstra, J. M., T. M. Boucher, T. H. Ricketts, and C. Roberts. 2005. Confronting a biome crisis: global disparities of habitat loss and protection. Ecology Letters 8(1):23-29. http://dx.doi. org/10.1111/j.1461-0248.2004.00686.x

Hunter, W. C., J. G. Dickson, D. N. Pashley, and P. B. Hamel. 2002. Bird communities of southern forests. In Proceedings of the IUFRO conference on restoration of boreal and temperate forest documenting forest restoration knowledge and practices in boreal and temperate ecosystems. 28 April - 02 May Vijle, Denmark. [online] URL: http://www.treesearch.fs.fed.us/pubs/7125

Imhoff, D., and J. A. Baumgartner. 2006. Farming and the fate of wild nature: essays in conservation-based agriculture. University of California Press, Berkeley, California, USA. 
Johansson, D. J. A., and C. Azar. 2007. A scenario based analysis of land competition between food and bioenergy production in the U.S. Climate Change 82:267-291. http://dx.doi.org/10.1007/ s10584-006-9208-1

Johnson, R. J., J. A. Jedlicka, J. E. Quinn, and J. R. Brandle. 2011. Global perspectives on birds in agricultural landscapes. Pages 55-140 in W. B. Campbell and S. López Ortíz, editors. Integrating agriculture, conservation and ecotourism: examples from the field. Springer, Dordrecht, The Netherlands. http://dx.doi. org/10.1007/978-94-007-1309-3 3

Kareiva, P., and M. Marvier. 2012. What is conservation science? BioScience 62(11):962-969. http://dx.doi.org/10.1525/bio.2012.62.11.5

Krebs, J. R., J. D. Wilson, R. B. Bradbury, and G. M. Siriwardena. 1999. The second silent spring? Nature 400(6745):611-612. http:// dx.doi.org/10.1038/23127

Land Trust Alliance. 2010. 2010 National Land Trust census report: a look at voluntary land conservation in America. Lincoln Institute of Land Policy, Cambridge, Massachusetts, USA.

Levin, S. A. 1992. The problem of pattern and scale in ecology: the Robert H. MacArthur Award Lecture. Ecology 73 (6):1943-1967. http://dx.doi.org/10.2307/1941447

Liu, J., T. Dietz, S. R. Carpenter, M. Alberti, C. Folke, E. Moran, A. N. Pell, P. Deadman, T. Kratz, J. Lubchenco, E. Ostrom, Z. Ouyang, W. Provencher, C. L. Redman, S. H. Schneider, and W. W. Taylor. 2007. Complexity of coupled human and natural systems. Science 317(5844):1513-1516. http://dx.doi.org/10.1126/ science. 1144004

Martin, L. J., J. E. Quinn, E. C. Ellis, M. R. Shaw, M. A. Dorning, L. M. Hallett, N. E. Heller, R. J. Hobbs, C. E. Kraft, E. Law, et al. 2014. Conservation opportunities across the world's anthromes. Diversity and Distributions 20(7):745-755. http://dx. doi.org/10.1111/ddi.12220

Matson, P. A., W. J. Parton, A. G. Power, and M. J. Swift. 1997. Agricultural intensification and ecosystem properties. Science 277 (5325):504-509. http://dx.doi.org/10.1126/science.277.5325.504

McKenzie, A. J., S. B. Emery, J. R. Franks, and M. J. Whittingham. 2013. Forum: Landscape-scale conservation: collaborative agrienvironment schemes could benefit both biodiversity and ecosystem services, but will farmers be willing to participate? Journal of Applied Ecology 50(5):1274-1280.

Mize, C. W., J. R. Brandle, M. Schoeneberger, and G. Bentrup. 2008. Ecological development and function of shelterbelts in temperate North America. Pages 27-54 in S. Jose and A. M. Gordon, editors. Toward agroforestry design. Springer, Dordrecht, The Netherlands. http://dx.doi.org/10.1007/978-1-4$\underline{020-6572-9 \quad 3}$

Monticino, M., M. Acevedo, B. Callicott, T. Cogdill, and C. Lindquist. 2007. Coupled human and natural systems: a multiagent-based approach. Environmental Modelling \& Software 22 (5):656-663. http://dx.doi.org/10.1016/j.envsoft.2005.12.017

National Conservation Easement Database (NCED). 2015. [online] URL: http://www.conservationeasement.us/easements/ download links
Partners in Flight Science Committee. 2012. Species assessment database. Version 2012. Partners in Flight. [online] URL: http:// rmbo.org/pifassessment

Pickett, S. R. A., and G. M. Siriwardena. 2011. The relationship between multi-cale habitat heterogeneity and farmland bird abundance. Ecography 34(6):955-969. http://dx.doi.org/10.1111/ j.1600-0587.2011.06608.x

Pimm, S. L., C. N. Jenkins, R. Abell, T. M. Brooks, J. L. Gittleman, L. N. Joppa, P. H. Raven, C. M. Roberts, and J. O. Sexton. 2014. The biodiversity of species and their rates of extinction, distribution, and protection. Science 344(6187). http://dx.doi. org/10.1126/science. 1246752

Powell, L. A. 2012. Common-interest community agreements on private lands provide opportunity and scale for wildlife management. Animal Biodiversity and Conservation 35:295-306.

Puckett, H. L., J. R. Brandle, R. J. Johnson, and E. E. Blankenship. 2009. Avian foraging patterns in crop field edges adjacent to woody habitat. Agriculture, Ecosystems \& Environment 131 (1-2):9-15. http://dx.doi.org/10.1016/j.agee.2008.08.015

Quinn, C. E., and M. E. Burbach. 2008. Personal characteristics preceding pro-environmental behaviors that improve surface water quality. Great Plains Research 18(1):103-114.

Quinn, C. E., J. E. Quinn, and A. C. Halfacre. 2015. Digging deeper: a case study of farmer conceptualization of ecosystem services in the American South. Environmental Management 56 (4):802-813. http://dx.doi.org/10.1007/s00267-015-0534-9

Quinn, J. E., J. R. Brandle, and R. J. Johnson. 2012. The effects of land sparing and wildlife-friendly practices on grassland bird abundance within organic farmlands. Agriculture, Ecosystems \& Environment 161:10-16. http://dx.doi.org/10.1016/j.agee.2012.07.021

Quinn, J. E., R. J. Johnson, and J. R. Brandle. 2014. Identifying opportunities for conservation embedded in cropland anthromes. Landscape Ecology 29(10):1811-1819. http://dx.doi.org/10.1007/ s10980-014-0098-8

Ramalho, C. E., and R. J. Hobbs. 2012. Time for a change: dynamic urban ecology. Trends in Ecology \& Evolution 27 (3):179-188. http://dx.doi.org/10.1016/j.tree.2011.10.008

Raworth, K. 2012. A safe and just space for humanity: can we live within the doughnut. Oxfam Policy and Practice: Climate Change and Resilience 8(1):1-26.

Rissman, A. R. 2013. Rethinking property rights: comparative analysis of conservation easements for wildlife conservation. Environmental Conservation 40(3):222-230. http://dx.doi.org/10.1017/ $\underline{\text { s0376892913000015 }}$

Rissman, A. R., J. Owley, M. R. Shaw, and B. B. Thompson. 2015. Adapting conservation easements to climate change. Conservation Letters 8(1):68-76. http://dx.doi.org/10.1111/ conl.12099

Sauer, J. R., J. E. Hines, J. E. Fallon, K. L. Pardieck, D. J. Ziolkowski Jr., and W. A. Link. 2014. The North American breeding bird survey, results and analysis 1966-2013. Version 01.30.2015. USGS Patuxent Wildlife Research Center, Laurel, Maryland, USA. 
Schoeneberger, M. M. 2009. Agroforestry: working trees for sequestering carbon on agricultural lands. Agroforestry Systems 75(1):27-37. http://dx.doi.org/10.1007/s10457-008-9123-8

Soulé, M. E. 1985. What is conservation biology? A new synthetic discipline addresses the dynamics and problems of perturbed species, communities, and ecosystems. Bioscience 35(11):727-734.

Soule, M. J., A. Tegene, and K. D. Wiebe. 2000. Land tenure and the adoption of conservation practices. American Journal of Agricultural Economics 82(4):993-1005. http://dx.doi. org/10.1111/0002-9092.00097

Strohbach, M. W., P. S. Warren, and M. N. Peterson. 2014. Urban wildlife science in coupled human-natural systems. Pages 33-53 in R. A., McCleery, C. E. Moorman, and M. N. Peterson, editors. Urban wildlife conservation. Springer, New York, New York, USA. http://dx.doi.org/10.1007/978-1-4899-7500-3 3

Tallis, H., P. Kareiva, M. Marvier, and A. Chang. 2008. An ecosystem services framework to support both practical conservation and economic development. Proceedings of the National Academy of Sciences of the United States of America 105(28):9457-9464. http://dx.doi.org/10.1073/pnas.0705797105

Terando, A. J., J. Costanza, C. Belyea, R. R. Dunn, A. McKerrow, and J. A. Collazo. 2014. The southern megalopolis: using the past to predict the future of urban sprawl in the southeast US. PLoS ONE 9(7):e102261. http://dx.doi.org/10.1371/journal.pone.0102261

Tershy, B. R., K. Shen, K. M. Newton, N. D. Holmes, and D. A. Croll. 2015. The importance of islands for the protection of biological and linguistic diversity. Bioscience 65(6):592-597. http://dx.doi.org/10.1093/biosci/biv031

Turner, B. L., P. A. Matson, J. J. McCarthy, R. W. Corell, L. Christensen, N. Eckley, G. K. Hovelsrud-Broda, J. X. Kasperson, R. E. Kasperson, A. Luers, M. L. Martello, S. Mathiesen, R. Naylor, C. Polsky, A. Pulsipher, A. Schiller, H. Selin, and N. Tyler. 2003. Illustrating the coupled human-environment system for vulnerability analysis: three case studies. Proceedings of the National Academy of Sciences of the United States of America 100(14):8080-8085. http://dx.doi.org/10.1073/pnas. 1231334100

Udawatta, R. P., H. E. Garrett, and R. Kallenbach. 2011. Agroforestry buffers for nonpoint source pollution reductions from agricultural watersheds. Journal of Environmental Quality 40(3):800-806. http://dx.doi.org/10.2134/jeq2010.0168

U.S. Department of Agriculture (USDA). 2002. Major uses of land in the United States, 2002. Economic Information Bulletin No. 14. Economic Research Service/USDA, Washington, D.C., USA. [online] URL: https://www.ers.usda.gov/webdocs/publications/ eib14/12983 eib14fm 1 .pdf

Wallace, G. N., D. M. Theobald, T. Ernst, and K. King. 2008. Assessing the ecological and social benefits of private land conservation in Colorado. Conservation Biology 22(2):284-296. http://dx.doi.org/10.1111/j.1523-1739.2008.00895.x

Withgott, J. H., and K. G. Smith. 1998. Brown-headed Nuthatch (Sitta pusilla). No. 24 in A. Poole, editor. The birds of North America. Cornell Lab of Ornithology, Ithaca, New York, USA. http://dx.doi.org/10.2173/bna.349
Wood, J. M., and J. E. Quinn. 2016. Local and landscape metrics identify opportunities for conserving cavity-nesting birds in a rapidly urbanizing ecoregion. Journal of Urban Ecology 2(1): juw003. http://dx.doi.org/10.1093/jue/juw003

World Bank. 2015. Terrestrial protected areas (\% of total land area). World Bank, Washington, D.C., USA. [online] URL: http://data.worldbank.org/indicator/ER.LND.PTLD.ZS 